\title{
New Perspective On The Haplosporidian Parasites Of Molluscs
}

\author{
Arzul Isabelle ${ }^{1}$, Carnegie Ryan B. ${ }^{2, *}$ \\ 1 IFREMER, Laboratory of Genetics and Pathology Av de Mus de Loup-17390 La Tremblade, France \\ 2 Virginia Institute of Marine Science College of William \& Mary P.O. Box 1346 Gloucester Point, VA \\ 23062, USA \\ * Corresponding author : Ryan B. Carnegie, Tel.: +804.684 7713 ; fax: +804.684.7796 ; \\ email address : carnegie@vims.edu
}

\begin{abstract}
:
The protist phylum Haplosporidia comprises over 40 described species with representatives infecting a range of mollusc hosts, including several ecologically and economically significant pathogens. Continuing exploration of haplosporidian diversity has added ten new species in recent years and brought the phylogenetics of the group into somewhat clearer focus, with monophyletic Bonamia and Minchinia lineages continuing to be supported. However, the addition of new sequences to phylogenetic analyses has left the paraphyletic genus Haplosporidium's picture less resolved. It is not clear that even two genera will be enough to accommodate the species presently drawn to the Haplosporidium regions of the haplosporidian tree. In this review, we summarize recent findings in haplosporidian diversity and phylogenetics, and provide a synthesis of our understanding of the life cycles and environmental influences on haplosporidians, with particular emphasis on the important pathogens Haplosporidium nelsoni and Bonamia ostreae. Additionally, we consider the evolution of the "microcell haplosporidian" lifestyle of Bonamia parasites, and suggest that colonization of high-density oyster host populations in relatively stable euhaline marine environments may have been an important development favoring the evolution of the microcell haplosporidian life strategy.
\end{abstract}

Keywords : Haplosporidium, Bonamia, Minchinia, MSX disease, Haplosporidiosis, Bonamiosis 


\section{INTRODUCTION}

Since the emergence of Haplosporidium nelsoni (or MSX, for "multinucleate sphere unknown") in the Delaware Bay in 1957 and Chesapeake Bay in 1959 (Andrews, 1962; Haskin et al., 1966), haplosporidian parasites of molluscs have been considered major pathogens of concern for aquatic animal health managers and shellfish industries around the world. They were one of the first groups to be recognized as significant pathogens of bivalve molluses, with only Perkinsus marinus, identified in the oyster Crassostrea virginica in the Gulf of Mexico in 1948 (at that time as Dermocystidium marinum (Mackin et al., 1950)), coming to our attention earlier. And the haplosporidians have been responsible for some of the most significant and consequential marine disease epizootics on record. The H. nelsoni outbreak along the MidAtlantic coast of the USA devastated oyster populations and caused significant economic disruption of coastal communities dependent on them. Oyster mortality associated with this outbreak exceeded 90\% (Ford and Haskin, 1982; Haskin and Andrews, 1988), producing significant financial losses for the oyster industries in these estuaries (e.g., Haven et al., 1978), from which they only recently have begun to recover. The microcell haplosporidian Bonamia ostreae was no less impactful on oyster Ostrea edulis populations in Europe. First observed at Île Tudy in Brittany, France in 1979 (Pichot et al., 1980), B. ostreae caused substantial destruction of O. edulis populations in France before spreading through much of Atlantic coastal Europe where its activity was most intense (Van Banning, 1991; Hudson and Hill, 1991; Montes, 1990; McArdle et al., 1991). Damage from B. ostreae compounded that caused by Marteilia refringens, which emerged in O. edulis in France a decade earlier (Comps, 1970; Grizel et al., 1974), and by the gill iridovirus that drove the Portuguese oyster Crassostrea angulata essentially to commercial extinction (Marteil, 1968). The combination of these events led to the massive 
importation to France and then other European countries of the Pacific oyster Crassostrea gigas (Grizel and Héral, 1991; Ruesink et al., 2005), a landmark development in the diaspora of this now globally significant commercial species.

In the decade since the last review of the haplosporidians by Burreson and Ford (2004), ten new haplosporidian species have been described (Table 1) in addition to numerous observations of novel unnamed haplosporidians (Table 2), and our knowledge of key species like H. nelsoni and the Bonamia parasites has deepened. The objective of this paper will be to revisit the phylogeny of the haplosporidians based on the incorporation of these new records and to provide the first synthesis on Bonamia and the haplosporidians, with particular attention to the haplosporidians that continues to be the most significant in terms of their impacts, $H$. nelsoni and B. ostreae.

\section{PHYLOGENY}

\subsection{New perspective on haplosporidian interrelationships}

Since the major phylogenetic analysis of the haplosporidians by Reece et al. (2004), the phylogeny of the group has continued to come into clearer focus with the continual characterization of new species. Reece et al. (2004) determined the relationships among fifteen haplosporidians for which SSU rDNA and actin gene sequences were available. They identified undescribed parasites of the spot prawn Pandalus platyceros (Bower and Meyer, 2002) and abalone Haliotis iris (Hine et al., 2002; Reece and Stokes, 2003) as basal to the established haplosporidian genera Urosporidium, Haplosporidium, Minchinia, and Bonamia, with Urosporidium, represented in their analysis by Urosporidium crescens and a Urosporidium $\mathrm{sp.}$ hyperparasitic in the trematode Stictodora lari from the whelk Battilaria australis, as basal to the 
other genera. The genera Bonamia and Minchinia were resolved as sister genera, the former including B. ostreae as well as Bonamia exitiosa, which we recognize Bonamia sp. and Mikrocytos roughleyi from the Reece et al. (2004) analysis to represent (Carnegie et al. 2014), and the latter represented by Minchinia tapetis, Minchinia chitonis, Minchinia teredinis, and an undescribed parasite from the clam Cyrenoida floridana. Haplosporidium, comprising the remainder of the sequences in the analysis, was paraphyletic, however, with Haplosporidium costale and the sister species Haplosporidium pickfordi and Haplosporidium lusitanicum forming a monophyletic clade sister to the Bonamia-Minchinia clade but with $H$. nelsoni and Haplosporidium louisiana basal to Bonamia-Minchinia and the other Haplosporidium species. Paraphyly of Haplosporidium has consistently been demonstrated in all subsequent analyses with additional sequences, and will require resolution through the creation of new genera to accommodate those presently in this genus; which lineage among these deserves to retain the Haplosporidium designation cannot be determined, however, without determination of the position of Haplosporidium scolopli, the type Haplosporidium species, a parasite of the polychaete Scoloplos mülleri (Caullery and Mesnil 1899, Burreson and Reece 2006).

The molecular characterization of additional haplosporidians has, in some ways, not dramatically altered the tree topology illustrated by Reece et al. (2004). More recent analyses have continued to identify the $P$. platyceros and $H$. iris parasites as basal haplosporidians, joined by an undescribed parasite of the clam Ruditapes decussatus in Spain (Novoa et al. 2004) but with the relationships among these three parasites not clearly resolved; Urosporidium as basal to the other established genera; and the derived genera Bonamia and Minchinia as reciprocally monophyletic (Azevedo et al. 2006; Carnegie et al. 2006; Siddall and Aguado 2006; Bearham et al. 2007; Nunan et al. 2007; Ford et al. 2009; Vea and Siddall 2011; Molloy et al. 2012; 
Stentiford et al. 2013; Engelsma et al. 2014; Ituarte et al. 2014). Bonamia is now represented additionally by Bonamia perspora, a parasite of the oyster Ostrea equestris (= Ostrea stentina, Shilts et al. 2007) in North Carolina, USA (Carnegie et al. 2006), for which there is weak evidence of a sister relationship to B. ostreae (Engelsma et al. 2014), and an undescribed Bonamia sp. from the oyster Dendostrea sandvicensis in Hawaii that appears to be the basal representative of this genus based on its SSU rDNA sequence (Engelsma et al. 2014; Hill et al. 2014; Fig. 1). Minchinia now includes Minchinia occulta, infecting oyster Saccostrea cuccullata in Western Australia (Bearham et al. 2008a) and Minchinia mercenariae, infecting clam Mercenaria mercenaria in Virginia, USA (Ford et al. 2009). A parasite detected genetically in mussel Mytilus edulis from Wales appears to be a Minchinia species as well (Lynch et al. 2014). While the sister relationship between Bonamia and Minchinia would seem to be robustly supported based on the work cited above, it should be noted that a maximum likelihood analysis illustrated by Ituarte et al. (2014) produced a divergent result, with Minchinia sister to a clade comprising Bonamia plus most of the other Haplosporidium species (with only H. louisiana the exception). There is no morphological or other basis for presuming a sister relationship between Bonamia and Minchinia, so this observation underscores the fact that conclusions concerning the interrelationships among haplosporidian genera should be made with caution.

What has become less certain with the addition of new species to the analysis in recent years has been whether even the Haplosporidium species exclusive of $H$. louisiana and $H$. nelsoni can be accommodated on a single monophyletic Haplosporidium clade. While analyses with the limited available sequences (H. costale, $H$. pickfordi, H. lusitanicum, and the recently described abalone parasite Haplosporidium montforti (Azevedo et al. 2006)) in the last decade suggested they could (e.g., Azevedo et al. 2006, Carnegie et al. 2006, Siddall and Aguado 2006, 
Nunan et al. 2007), more recent work has been less persuasive of their monophyly. Stentiford et al. (2013) found strong (84\% bootstrap) support for a clade including their newly described crab parasite Haplosporidium littoralis, H. montforti, limpet parasite Haplosporidium tuxtlensis (Vea and Siddall 2011), a haplosporidian detected from the polychaete Syllis nipponica (Siddall and Aguado 2006), H. pickfordi, and H. lusitanicum. Four other Haplosporidium spp., H. costale, Haplosporidium edule, a parasite of oyster O. edulis from Europe, and recently described zebra mussel parasite Haplosporidium raabei (Molloy et al. 2012) formed a second, more weakly (67\% bootstrap) supported clade, but there was only 55\% bootstrap support for uniting these two clades on a single lineage. Ituarte et al. (2014), describing the limpet parasite Haplosporidium patagon, found strong (100\% bootstrap) support for a sister relationship to the S. nipponica parasite, but for little else besides a close relationship among $H$. littoralis, $H$. montforti, $H$. lusitanicum, H. pickfordi, and H. tuxtlensis, which were recovered on a monophyletic clade in both parsimony and maximum likelihood analyses. In general, with regard to the Haplosporidium region of the haplosporidian phylogeny, we can conclude based on presently available data that $H$. littoralis, $H$. montforti, $H$. lusitanicum, $H$. pickfordi, and $H$. tuxtlensis do comprise a clade of closely related species; that $H$. raabei and $H$. edule, and $H$. costale and the Haplosporidium sp. from O. edulis, are pairs of sister species that may (see Fig. 1) or may not (Ituarte et al. 2014) represent another monophyletic lineage; that the $S$. nipponica parasite and $H$. patagon, the parasites from the shrimp Litopenaeus vannamei in Belize (Nunan et al. 2007) and from Indonesia (Utari et al. 2012), and H. nelsoni and the amphipod parasite Haplosporidium diporeiae (Winters and Faisal, 2014) are three additional pairs of sister species; but that the relationships among these lineages are also not well resolved (Fig. 1). We note also a growing uncertainty about the position of $H$. louisiana, which has reliably been positioned as basal to $H$. 
nelsoni and all the other Haplosporidium, Bonamia, and Minchinia spp. (Reece et al. 2004; Azevedo et al. 2006; Carnegie et al. 2006; Siddall and Aguado 2006; Bearham et al. 2007; Nunan et al. 2007; Ford et al. 2009; Vea and Siddall 2011; Molloy et al. 2012; Stentiford et al. 2013; Engelsma et al. 2014). While the maximum likelihood analysis of Ituarte et al. (2014) found $H$. louisiana to reside in this position, both that study's parsimony analysis as well as our updated analysis with all the currently characterized haplosporidian species (Fig. 1) placed $H$. louisiana in a more derived position among the other Haplosporidium spp. Better resolution of the haplosporidian phylogeny will await more intensive future analyses with additional loci. We must envision the possibility that not all of the lineages in the Haplosporidium region of the phylogeny may be accommodated within even two genera, depending on where $H$. scolopli lies in the phylogeny (Burreson and Reece 2006).

\subsection{Haplosporidian cell forms and phylogeny}

The major recent discovery with regard to haplosporidian cell forms was the observation of spores in B. perspora with a hinged operculum and ornamentation derived from the spore wall (Carnegie et al. 2006). As Burreson and Reece (2006) suggested, this confounds distinctions between Haplosporidium and Bonamia, which now have no morphological basis. Recent species descriptions have, however, continued to reinforce the conventional distinction between Haplosporidium and Minchinia: that while both have spores with hinged opercula, ornamentation, if present, is derived from the spore wall in the former genus, and from epispore cytosplasm in the latter. H. tuxtlensis, $H$. montforti, and H. raabei all possess filaments extending from the spore wall, and all have affinities to the (paraphyletic) Haplosporidium region of the phylogeny (Azevedo et al. 2006; Vea and Siddall 2011; Molloy et al. 2012)(Fig. 1). H. patagon, 
also with affinities to the Haplosporidium region of the phylogeny, possesses spores with hinged opercula that, while they do display no spore wall-derived ornamentation (Ituarte et al. 2014), also display no ornamentation derived from epispore cytoplasm; assignment of $H$. patagon to Haplosporidium thus makes sense. M. mercenariae and M. occulta both have clear phylogenetic affinities to Minchinia (Fig. 1), and M. mercenariae spores are covered with epispore cytoplasm from which numerous filaments extend (Ford et al. 2006). Assignment of M. mercenariae to Minchinia thus is morphologically justified. M. occulta spores present something of a strange case, in that the epispore cytoplasm seems to be condensed into a "network of branching microtubule-like structures covering the entire spore including the opercula lid" (Bearham et al. 2008a). Nevertheless, the lack of attachment of these structures to the spore wall and the absence of any other spore wall-derived ornamentation argues against a morphological affinity to Haplosporidium. Assignment to Minchinia, rather than Haplosporidium, again may be morphologically justified based on a reasonable interpretation of this parasite's "microtubulelike" spore ornamentation.

Hine et al. (2009) considered whether ultrastructure more generally might offer insight into what features are important in reflecting haplosporidian phylogeny. A number of features, like patterns in haplosporogenesis, may be of taxonomic use, but more systematic evaluation of haplosporidian ultrastructure vis-à-vis phylogeny will be necessary before we can establish this to be the case. "The taxonomy of haplosporidians needs a thorough revision", in the words of Hine et al. (2009), and a more systematic phylum-wide ultrastructural analysis should be a part of this.

\subsection{Haplosporidian phylogeny and host distribution}


Is there a compelling host signal in the haplosporidian phylogeny? While the signal is not strong, this is not to say there is no pattern at all. Bonamia spp., to our knowledge, continue to be known exclusively as parasites of oysters (Engelsma et al. 2014). Minchinia spp. infect a range of molluscs, but to our knowledge nothing else (Burreson and Ford 2004; Bearham et al. 2008; Ford et al. 2009). Urosporidium spp. infect various free-living as well as parasitic worm taxa (Burreson and Ford 2004). It is the Haplosporidium spp. that are associated with the broadest range of hosts, from polychaetes, oligochaetes and nemerteans to molluscs, crustaceans, and echinoderms (Burreson and Ford 2004), and there is little pattern to host preference within the Haplosporidium region of the phylogeny. Within the well supported H. tuxtlensis-H. pickfordiH. lusitanicum-H. montforti-H. littoralis clade, hosts include four gastropod molluscs and a crab. On the $S$. nipponica-parasite- $H$. patagon clade, a polychaete and a gastropod are hosts. Host range narrows on the H. raabei-H. edule-H. costale-O. edulis parasite clade (four bivalve molluscs) and on the clade comprising the two shrimp parasites (infecting the same host, $L$. vannamei), but the picture that remains is one of little host-parasite co-evolutionary phylogenetic signal within the genus Haplosporidium.

As will be described in the section below on Life Cycles, it is important to note, though, that while Bonamia spp. (with the possible exception of B. perspora) are believed to be directly transmissible among oyster hosts (Engelsma et al. 2014), no evidence exists for direct transmission in other haplosporidian genera, with $H$. pickfordi being the sole possible exception (Barrow 1965). The possibility that parasites like H. nelsoni require one or more intermediate hosts has long been considered seriously (Haskin and Andrews 1988). If complex life cycles are generally the reality for conventional (i.e., non-Bonamia) haplosporidians, the distribution of host types on the haplosporidian phylogeny could reflect the observation of parasites at different 
stages of their complex life cycles — final host in one case, intermediate host in another-which could obscure genuine co-evolutionary signal. A related consideration is that where closely related parasite species have been documented from very different hosts, we could potentially be gaining a window into the different hosts involved in the cycles of these close relatives if the life cycles have been evolutionarily conserved. The sister relationship between $H$. nelsoni and $H$. diporeiae, for example, could point to molluscan and crustacean hosts being required in the life cycle of each.

\subsection{Additional new perspective on haplosporidian phylogeny}

We might ask whether significant additional haplosporidian diversity remains to be discovered. The answer, perhaps not expectedly, would seem to be a resounding yes. Hartikainen et al. (2014a) screened environmental DNA samples from the United Kingdom to South Africa, and identified a number of novel phylogenetic lineages within the Haplosporidia. While nothing is known about the biology of these organisms, including their hosts, there surely is a diversity of haplosporidians waiting to be characterized to enrich our understanding of the evolution of this group.

The more interesting and important recent observation was the discovery that the enigmatic oyster pathogen Mikrocytos mackini and its relatives have affinities to the supergroup Rhizaria, with a potential close relationship to the haplosporidians (Burki et al. 2013). This finding was reinforced by subsequent work by Hartikainen et al. (2014b), and "has profound implications for our understanding of the biology and ecology of haplosporidians and Mikrocytos and should ignite a new phase of research on these groups" (Carnegie and Engelsma 2014). 


\section{LIFE CYCLES}

\subsection{Specificity and prevalence}

Although Bonamia and Haplosporidium genera belong to the same phylum, the Haplosporidia, they include parasite species that display diverse life strategies (e.g., Figs. 2,3). Bonamia and Haplosporidium species are mostly described from marine invertebrates. However, a few infections with Haplosporidium have been reported from freshwater including from snails in lakes in the USA, amphipods of the genus Diporeia (Winters and Faisal, 2014) and zebra mussels Dreissena (Burreson and Ford, 2004). Up to now, the genus Bonamia has included species only characterized from oysters. The flat oyster $O$. edulis is the only natural host species known for $B$. ostreae whereas $B$. exitiosa has been detected in a wider range of oyster species including flat oysters from the genus Ostrea and cupped oysters from Crassostrea and Saccostrea genera (Hill et al. 2014). These different reports suggest that the genus Haplosporidium is more generalist than Bonamia.

The prevalence of infection with most of haplosporidian parasites is often low and they do not appear to be important pathogens because of this low prevalence. For instance, mean prevalence of $H$. armoricanum in O. edulis in Galicia, Spain, was never found to exceed $4.1 \%$ (da Silva et al., 2005). Although C. gigas is susceptible to H. nelsoni, prevalence of the infection is usually low, below 4\% (Garcia et al. 2006; Kamaishi and Yoshinaga, 2002; Lynch et al. 2013), and its detection has never been associated with significant mortalities in this oyster species (Elston, 1999; Burreson et al. 2000). Another example is B. perspora in O. equestris (=O. stentina), which was detected in only $1.4 \%$ of tested oysters in 2004 and 2005 (Carnegie et al., 2006). However, some species cause high mortality in commercially important hosts, with $H$. nelsoni in C. virginica and B. ostreae in $O$. edulis being prime examples. Initial observations of 
these pathogens were associated with host mortality rates approaching $100 \%$. Both of these examples were revealed after pathogen introduction from other countries, Asia for $H$. nelsoni (Burreson et al., 2000) and the USA for B. ostreae (Elston et al., 1986), and the great impacts of B. ostreae and H. nelsoni, more than for any other haplosporidian parasites, clearly seem to reflect pathogen encounters with naïve and highly susceptible hosts. With populations of susceptible hosts continuing to persist, the impacts of these major pathogens have not fully waned.

Bonamia and Haplosporidium parasites species can be found in different developmental oyster stages from larvae, as demonstrated for B. ostreae in the flat oyster O. edulis (Arzul et al., 2011), to adults. B. ostreae-caused mortality can sometime affect oysters less than 1 year old. Lynch et al. (2005) found young prespawning flat oysters to be susceptible to infection by $B$. ostreae, with a high prevalence and intensity of infection developing over a 6-month period. Lallias et al. (2008) decribed mortality associated with B. ostreae infection in 6-month-old juvenile $O$. edulis. However, older individuals appear more susceptible to the disease (Balouet et al., 1983; Grizel,1985; Robert et al., 1991; Culloty and Mulcahy, 1996; Engelsma et al., 2010) and death usually occurs concurrently with the highest level of infection intensity (Bréhelin etal., 1982; Montes et al., 2003). While insufficient data exist to make conclusions about the sizespecificity of B. exitiosa infection in its numerous hosts (Engelsma et al., 2014), B. exitiosa infection of oyster C. ariakensis in experimental culture in the southeastern U.S.A. was more prevalent and lethal in small, young of the year oysters (Burreson et al., 2004; Bishop et al., 2006).

Sporulation of $H$. nelsoni appears prevalent in juveniles where it causes disruption of the digestive tubule epithelia and is sometimes associated with mortalities (Barber et al., 1991; 
Burreson, 1994; Sunila et al.; 2000). Although haplosporidian parasites can develop in juveniles sometimes leading to their death, mortalities mostly occur in older individuals suggesting that most of the infected oysters have finally spawned at least once before dying. Particularly for the highly pathogenic species like $H$. nelsoni and B. ostreae, allowing one or more cycles of host reproduction before mortality would be one key to the maintenance of susceptible host genotypes in a population.

\subsection{Cell forms and parasite transmission}

Bonamia species are mostly intracellular, infecting hemocytes (Fig. 4A). The intimacy of the intracellular parasite-host cell relationship usually limits the range of susceptible hosts which can notably explain the narrow host range of these parasites. Infection with Bonamia parasites is usually systemic and associated with global hemocyte infiltration. Unicellular cells are typically presented, although binucleate and plasmodial cells can be observed. Plasmodia seem to be more common for infection with $B$. exitios $a$ than with $B$. ostreae where such parasite forms are more often observed in moribund or dead oysters (Bréhelin et al., 1982). Bonamia perspora is the only Bonamia species for which spores have been observed thus far. B. perspora is larger (2-6 $\mu \mathrm{m})$ than other Bonamia spp. in its unicellular forms and rarely observed in hemocytes or other host cells. It is found throughout connective tissues of infected oysters and is more abundant at the base of the epithelia of the gut and hemolymph sinuses (Carnegie et al., 2006; Fig. 4B). The extracellular habits of $B$. perspora along with its spore production are sharp departures from the habits of other Bonamia species, and more reflective of the habits of other haplosporidians.

Haplosporidium species are typically extracellular, invading connective tissues or epithelia in the case of oyster parasites. H. nelsoni occurs initially in the gill epithelium and 
subsequently become dispersed through all tissues. Plasmodia are the most commonly observed stages of $H$. nelsoni in oysters. These multinucleated forms are from 5 to $>50 \mu \mathrm{m}$ in diameter, depending on the number and size of nuclei they contain. Sporulation, when observed, generally occurs in the epithelium of the digestive diverticula in oysters with advanced infections (Fig. 4C). Haplosporidium species other than H. nelsoni sporulate in connective tissues. During sporulation, plasmodia develop into sporocysts, with spore walls forming around each nucleus. Spores are presumably released into the environment upon death of the host.

Spores are stages enabling parasites surviving under detrimental conditions. These detrimental conditions could occur in the host and or in the environment. Spore fate is unknown. Intermediate hosts for haplosporidian parasites have not been identified, and repeated attempts to transmit $H$. nelsoni directly from oyster to oyster by injection of spores or plasmodia or cohabitation between infected and non-infected oysters have never been successful. Requirement for an intermediate host to complete the life cycle is suspected and supported by model simulations (Powell et al., 1999; Burreson and Ford, 2004). Juveniles of C. virginica produced in a $H$. nelsoni-free hatchery could be infected by feeding tanks with water originated from an area overlaying naturally infected oysters beds and filtered at $1 \mathrm{~mm}$ (Sunila et al., 2000). This experiment suggests that if an intermediate host is required it should be smaller than $1 \mathrm{~mm}$ in size.

The detection of the parasite at very low prevalence and intensity in $C$. gigas, for example in France (Garcia et al., 2006), indicates that H. nelsoni can survive and complete its life cycle outside the susceptible species $C$. virginica. The low prevalence usually reported supports the hypothesis that the parasite can incidentally infect oysters but might rather target other host species. These observations raise questions about the role played by oysters in the life 
cycle of MSX. The high abundance of $H$. nelsoni in the environment (Ford et al., 2009) and great infection pressure on oysters (Carnegie and Burreson, 2011) indicate that the parasite continues to thrive despite its diminished prevalence in oyster populations, a suggestion that $C$. virginica may be nothing more than an aberrant host (Haskin and Andrews, 1988).

In contrast to conventional haplosporidian parasites, B. ostreae and B. exitiosa can be transmitted directly suggesting that an intermediate host is not required for the parasite to complete its life cycle. Infection of $B$. ostreae can be reproduced experimentally by injecting parasites isolated from highly infected oysters (Miahle et al., 1988) and by cohabitation of infected oysters with uninfected individuals (Elston et al., 1986; Hervio et al., 1995). Although direct transmission of $B$. ostreae is possible, the parasite may be able to use additional routes of transmission. Lynch et al. (2007) detected parasite DNA in eight benthic macroinvertebrates and 19 grouped zooplankton samples. Some of these DNA-positive species were then used in laboratory transmission trials and transmission of $B$. ostreae was effected to two naïve oysters cohabiting with the brittle star, Ophiothrix fragilis (Lynch et al., 2006). Nevertheless, considering the correlation between density of oysters and prevalence of bonamiosis (Grizel, 1985; Hudson and Hill, 1991), the parasite mainly depends on flat oysters O. edulis for its survival and spread, and other aquatic organisms might not be involved as important carriers or transmitters (Van Banning, 1988).

As with $H$. nelsoni infection, release of B. ostreae is thought to peak when oyster death occurs. Observation of parasites in the epithelium of infected oysters collected before their death (Fig. 5) suggest that the parasite can be transmitted during the life of infected oysters and not only when they die. Detection of parasite DNA not only by PCR but also by in situ hybridization in several pools of larvae incubating in spawning oyster indicates that larvae are susceptible to $B$. 
ostreae and can contribute spreading the disease during their planktonic period of life. The detection of the parasite in cells surrounding the visceral cavity of larvae suggests that the parasites are ingested by larvae during the period of larvae incubation.

\section{ENVIRONMENTAL INFLUENCES ON HAPLOSPORIDIAN-CAUSED DISEASES}

\subsection{Temperature, salinity, and annual cycles}

Dynamics of haplosporidians in their hosts is seasonal and depends on environmental parameters. H. nelsoni is highly sensitive to environmental conditions, especially temperature and salinity, which influence both geographic distribution and seasonal infection patterns (Ford \& Haskin, 1982; Hofmann et al., 2001; Burreson and Ford, 2004). In eastern oysters in Delaware Bay infection with $H$. nelsoni shows a peak of prevalence in autumn followed by a decrease in the late winter due to mortality of heavily infected oysters and mortality of parasites caused by exposure to low winter temperatures. Infection level then increases again in the early spring and is followed by a rapid decline in the late spring. At this time, parasites might sporulate, leading to host death. These observations allowed identification of two periods of infection: (i) earlysummer infections which result in immediate late-summer and fall deaths and (ii) late-summer and fall infections which remain subclinical for months and are usually not expressed as mortalities until summer of the following year (Andrews, 1982). Tolerance of H. nelsoni plasmodia to change in salinity was evaluated in vitro and produced results similar to field observations and in vivo tests in which MSX prevalence decreases at salinities below 20. More

particularly, in vitro experiments showed a rapid destruction of $H$. nelsoni below 10 (Ford and Haskin, 1988). 
A mathematical model of MSX disease has been developed based on physiological processes of both host and parasite. This model suggests that temperature has a dominant effect on this cycle as well as on transmission especially under high salinity conditions. However, salinity also becomes an increasingly important factor when simulations are made under varied salinity regimes as would be found within estuaries (Paraso et al., 1999). When a cold winter is followed by a year with low salinity, prevalence and intensity of the disease are reduced. When environmental conditions moderate, the disease occurs again as has been observed along the northeast coast of United States (Burreson and Ford, 2004). This model takes into consideration the two life forms of the parasite: the plasmodial stage which is most prevalent and the spore stage which develops almost exclusively in juvenile oysters (Barber et al., 1991; Burreson, 1994). The model hypothesizes that sporulation depends on oyster food availability (Hoffman et al., 2001). Impact of climate change on the disease has been tested using this mathematical model to understand the apparent northward spread of MSX disease and its intensification in Chesapeake Bay (Burreson and Ford, 2004).

Interestingly, the comparison between the life cycle of the sympatric haplosporidian parasites $H$. nelsoni and $H$. costale suggests that the latter is a better adapted parasite. $H$. costale exhibits a regular annual cycle with mortality and infection periods occurring simultaneously in late spring. Sporulation occurs completely and consistently every year. A long incubation period allows regular oyster reproduction before mortalities occur. In contrast $H$. nelsoni is highly pathogenic and shows very long annual infection and mortality periods. It rarely sporulates and does not kill oysters promptly when it does because only the epithelia of digestive tubules are infected (Andrews 1982). Little is known about the seasonal life cycles of other conventional haplosporidian parasites, but the comparison of $H$. nelsoni with $H$. costale clearly suggests that 
the former displays a much less regular cycle, perhaps further evidence that, for H. nelsoni, $C$. virginica is an aberrant host.

Bonamiosis has been reported in different ecosystems from estuaries to open sea and at different latitudes suggesting no obvious correlation between the disease and environmental parameters like salinity and temperature. However, considering that direct transmission is possible, the parasite must remain for a certain period of time in the water column. In vitro experiments were undertaken to evaluate the survival of $B$. ostreae at different salinities and temperatures (Arzul et al., 2009). The parasite outside its host showed higher survival and esterase activities at $4{ }^{\circ} \mathrm{C}$ and $15^{\circ} \mathrm{C}$ than at $25^{\circ} \mathrm{C}$. Moreover, salinities over 35 seemed to favor survival and vitality of the parasite more than salinities below 20 . These results are supported by a field study showing that lower summer temperatures and higher summer salinities induce higher prevalence the following winter (Arzul et al., 2006). Similarly, a positive relationship was observed between B. ostreae prevalence and salinity in The Netherlands (Engelsma et al., 2010), and Flannery et al. (2014) observed reduced B. ostreae prevalence at a Clew Bay (Ireland) location where river output reduced salinity to as low as 9. Field and experimental studies carried out on B. exitiosa infecting the Asian oyster C. ariakensis in Atlantic coastal waters of the US showed a strong influence of the temperature on seasonal parasite cycling and on parasite pathogenicity (Carnegie et al., 2008; Audemard et al., 2008; Audemard et al. 2014). In this model, warm temperatures $\left(>20^{\circ} \mathrm{C}\right)$ favored new infections with high prevalence and development of the disease. Salinity seems to influence in the same manner the dynamics of infection with $B$. ostreae and B. exitiosa, higher salinities being associated with higher prevalence (Hine, 2002). Although oysters are poikilothermic and poikilosmotic animals with interactions between host and parasite strongly influenced by external factors, the development 
of disease is largely determined by the virulence of the pathogen and the defense capacity and responses of the host. The response of the host is also certainly influenced by environmental factors and studies investigating the impact of environmental parameters on the parasite inside the host do not allow distinguishing between the effect on the parasite and on the host responses. Prevalence of bonamiosis and oyster hemocyte activities have been investigated at different temperatures, with results showing that prevalence was greater at low temperature $\left(10^{\circ} \mathrm{C}\right)$ compared to higher temperature $\left(20^{\circ} \mathrm{C}\right)$ suggesting that low temperatures may affect defense capacities of the oyster and/or the capacity of the parasite to infect new oysters (Cochennec \& Auffret, 2002).

Although Bonamia parasites are detected in their hosts throughout the year, prevalence of infection with Bonamia species tends to show an annual pattern with two peaks occurring in winter/spring and in autumn (Hine 1991a ,b; Culloty \& Mulcahy, 1996; Cranfield et al., 2005; Arzul et al., 2006; Kroeck et al., 2008; Engelsma et al., 2010; Flannery et al., 2014; Lynch et al., 2014). Monitoring carried out in the lake Grevelingen in The Netherlands showed that prevalence with $B$. ostreae is higher in spring than in autumn and suggested that mortality of infected $O$. edulis occurred in spring- summertime (Engelsma et al. 2010). This period coincides with the spawning of the oysters. Similarly, in $O$. chilensis infected with B. exitiosa, Hine (1991a, b) considered that spawning stage is the most important condition for infection spread.

\subsection{Environmental dispersal}

Up to $58 \%$ of $B$. ostreae cells were found to be alive after one week of incubation at $15^{\circ} \mathrm{C}$ (Arzul et al., 2009), suggesting significant potential for dispersal of $B$. ostreae with water currents. This could contribute to rapid expansion of the geographic range of this parasite at least 
within a bay or in sites sharing commune water bodies. A five-year survey carried out on Bonamia sp. (presumably B. exitiosa) in the Argentinean native flat oyster O. puelchana in San Matias Gulf clearly defined the focus of infection from which that parasite spread, presumably via the water column. Infection focused from this site and reached close natural dense beds thanks to strong tide currents in this area (Kroeck et al., 2008). Environmental dispersion of the same parasite was considered in Foveaux Strait, southern New Zealand. There, movement of water in one tidal cycle is much greater than the observed spread of B. exitiosa in populations of O. chilensis over an entire year (Cranfield et al., 2005). These results led investigators to conclude that movement of disease particles in the current swept water column does not contribute much to the diffusion coefficient, which instead depends on hydrodynamic conditions adjacent to the seafloor (Cranfield et al. 2005). These conditions would be influenced by benthic habitat. While diffusion processes close to the seafloor are likely to have been important in the spread of disease over $<1 \mathrm{~m}$ scale of distance between oysters, turbulent processes could have been important in the spread of the epizootics over broader distances of $500 \mathrm{~m}$ and $5 \mathrm{~km}$ (Cranfield et al. 2005).

The environmental dispersal of conventional haplosporidians is little understood. $H$. nelsoni recolonizes beds from which it was purged by low salinities only slowly, a suggestion that recolonization could be tied to the reproduction and recruitment cycle of an intermediate host (Haskin and Andrews, 1988), but this remains purely speculative. Molecular data clearly point to the presence of $H$. nelsoni DNA in the water column, which may well be cells that can be captured on the gill surfaces of feeding bivalves (Ford et al. 2009), but little else is known about the environmental ecology of these pathogens. 
Clearly, the dynamics of haplosporidian parasites are strongly influenced by environmental factors, especially temperature and salinity. These factors impact vitality and survival of parasites outside their oyster hosts but influence as well the interactions between the parasite and their hosts. Bonamia species show a direct transmission from infected to naïve oysters with a stage in the water column that can contribute to spread the disease at different scale. In contrast, conventional haplosporidian species express spore stages and seem to require an intermediate host to reach a new oyster. These different strategies might influence the diversity of these two parasite groups and their co-evolution with their oyster hosts.

\section{CLOSING THOUGHTS: THE EVOLUTION OF MICROCELL HAPLOSPORIDIANS}

The haplosporidians remain an enigmatic group, and the unresolved life cycles of the conventional haplosporidians like $H$. nelsoni are only one reason why. How did the microcell haplosporidian strategy emerge from the relatively conserved and successful strategy of the conventional haplosporidians infecting molluscs, i.e., infection generally of connective tissues by plasmodial forms from which sporogony would proceed, and indirect transmission via some intermediated host(s)?

First, we might view the composite strategy of the microcell Bonamia parasites- that pursued by $B$. ostreae and B. exitiosa, but not B. perspora, the direct transmission of uninucleate forms primarily infective of oyster hemocytes - as the composite of three separate parasite adaptations. These are the shortening of the Bonamia life cycle to simply binary fission of uninucleate life stages; the development of the intrahemocytic tropism; and direct transmission. We can only speculate as to which of these, if any, came first, and whether any of these 
adaptations were related to each other. It may be, though, that a key to the evolution of Bonamia parasites was the colonization of a certain type of host.

Bonamia parasites infect oysters, but most are found in species that inhabit euhaline waters: oysters of the genera Ostrea most often. Part of this distribution with respect to salinity does relate to the salinity preferences of the oysters; Ostrea are not fundamentally estuarine species in the way that Crassostrea species are. There is some evidence, however, that at least one Bonamia species, B. exitiosa, is sharply limited at mesohaline salinities (Bishop et al., 2006; Audemard et al., 2008a,b). In terms of temperature, Bonamia parasites are most often documented from cool temperate areas (B. ostreae, B. exitiosa), with another awaiting description from D. sandvicensis in the tropics (Hill et al. 2014). These parasites tend to be associated, therefore with hosts that occur at high densities in environments that fluctuate only modestly in temperature and salinity. For a parasite that, in anything but a spore form, does not form a robust cell wall of any sort, a high-density oyster host population would be the best possible setting for it to experiment with direct transmission.

We might hypothesize that direct transmission arose by chance in a proto-Bonamia in some euhaline oyster population, as some of the uninucleate or plasmodial forms released from a dead oyster managed to directly colonize neighboring oyster hosts, and that this trait persisted because it was selectively advantageous over transmission via an intermediate host that may or may not be present or abundant and any given time. We could hypothesize that the shortening of the life cycle followed from that, as direct transmission by uninucleate cells or small plasmodia obviated the sporogonic pathway. The intrahemocytic habits of Bonamia are less obviously linked to the other adaptations, although colonization of host immune cells is a seclusive strategy pursued by numerous other parasites (e.g., Toxoplasma, Leishmania), and use of hemocytes 
proliferating in response to infection to rapidly increase infection intensity could clearly benefit transmission efficiency.

While $B$. perspora is the only Bonamia species to retain what we would interpret to be the ancestral haplosporidian traits of spore production and extracellular infection of host connective tissues (Carnegie et al., 2006), the parasite of $D$. sandvicensis in Hawaii is the basal Bonamia in SSU rDNA-based phylogenies, and this parasite appears to be a microcell haplosporidian. That $B$. perspora displays the ancestral life history yet is not basal genetically (based on available data) suggests that this and other Bonamia parasites may be capable of switching between life history modes depending, for example, on environmental circumstances (Hill et al., 2014). If such switching occurs, it would be interesting to ask which environmental circumstances favor one mode, and which favor the other, which could be one way to evaluate the hypothesis that colonization of dense oyster reefs favors direct transmission. The evolution and evolutionary ecology of the Bonamia parasites and the haplosporidians in general is a ripe area for future research.

\section{ACKNOWLEDGMENTS}

Jan McDowell assisted with the molecular phylogenetic analysis. Bruno Chollet provided the in situ hybridization image. This is VIMS Contribution No. XXXX.

\section{LITERATURE CITED}

Andrews, J.D., 1962. Oyster mortality studies in Virginia. IV. MSX in James River public seed beds. Proc. Natl. Shellfish Assoc. 53, 65-84. 
Andrews, J.D., 1982. Epizootiology of late summer and fall infections of oysters by Haplosporidium nelsoni, and comparison to annual life cycle of Haplosporidium costalis, a typical haplosporidan. J. Shellfish Res. 2, 15-23.

Arzul, I., Miossec, L., Blanchet, E., Garcia, C., Francois, C., Joly, J.P., 2006. Bonamia ostreae and Ostrea edulis: a stable host-parasite system in France? In: Proceedings of the 11th Symposium of the International Society for Veterinary Epidemiology and Economics (ISVEE), Cairns, Queensland, Australia, 6 - 11 August 2006, Theme 1 - Aquatic animal epidemiology: Crustacean and shellfish disease session, Volume T1-2.4.4: pp. 869-873. (For Open Access version of presentation see http://www.sciquest.org.nz/node/64451 and http://archimer.ifremer.fr/doc/00000/6381/).

Arzul, I., Gagnaire, B., Bond, C., Chollet, B., Morga, B., Ferrand, S., Robert, M., Renault, T., 2009. Effects of temperature and salinity on the survival of Bonamia ostreae, a parasite infecting flat oysters Ostrea edulis. Dis. Aquat. Org. 85, 67-75.

Arzul, I., Langlade, A., Chollet, B., Robert, M., Ferrand, S., Omner, E., Lerond, S., Couraleauy, Y., Joly, J.-P., François, C., Garcia, C., 2011. Can the protozoan parasite Bonamia ostreae infect larvae of flat oysters Ostrea edulis? Vet. Parasitol. 179, 69-76.

Audemard, C., Carnegie, R.B., Hill, K.M., Peterson, C.H., Burreson, E.M., 2014. Bonamia exitiosa transmission among, and incidence in, Asian oyster Crassostrea ariakensis under warm euhaline conditions. Dis. Aquat. Org. 110, 143-150. 
Audemard, C., Carnegie, R.B., Bishop, M.J., Peterson, C.H., Burreson, E.M., 2008a. Interacting effects of temperature and salinity on Bonamia sp. parasitism in the Asian oyster Crassostrea ariakensis. J. Invertebr. Pathol. 98, 344-350.

Audemard, C., Carnegie, R.B., Stokes, N.A., Bishop, M.J., Peterson, C.H., Burreson, E.M., 2008b. Effects of salinity on Bonamia sp. survival in the Asian oyster Crassostrea ariakensis. J. Shellfish Res. 27, 535-540.

Azevedo, C., Balseiro, P., Casal, G., Gestal, C., Aranguren, R., Stokes, N.A., Carnegie, R.B., Novoa, B., Burreson, E.M., Figueras, A., 2006. Ultrastructural and molecular characterization of Haplosporidium montforti n. sp., parasite of the European abalone Haliotis tuberculata. J. Invertebr. Pathol. 92, 23-32.

Balouet, G., Poder, J., Cahour, A., 1983. Haemocytic parasitosis: morphology and pathology of lesions in the French flat oyster, Ostrea edulis L. Aquaculture 34, 1-14.

Barber, R.D., Kanaley, S.A., Ford, S.E., 1991. Evidence for regular sporulation by Haplosporidium nelsoni (MSX) (Ascetospora: Haplosporidiidae) in spat of the American oyster, Crassostrea virginica. J. Protozool. 38, 305-306.

Barrow, J.H., Jr., 1965. Observations on Minchinia pickfordae (Barrow 1961) found in snails of the Great Lakes region. Trans. Amer. Microsc. Soc. 84, 587-593. 
Bearham, D., Spiers, Z., Raidal, S., Jones, J.B., Nicholls, P.K., 2007. Molecular characterization of a haplosporidian parasite infecting rock oysters Saccostrea cuccullata in north Western Australia. J. Invertebr. Pathol. 95, 33-40.

Bearham, D., Spiers, Z., Raidal, S., Jones, J.B., Nicholls, P.K., 2008. Spore ornamentation of Minchinia occulta n. sp. (Haplosporidia) in rock oysters Saccostrea glomerata (Born, 1778). Parasitol. 135, 1271-1280.

Bearham, D., Spiers, Z., Raidal, S., Jones, J.B., Burreson, E.M., Nicholls, P.K., 2008. Spore ornamentation of Haplosporidium hinei n. sp. (Haplosporidia) in pearl oysters Pinctada maxima (Jameson, 1901). Parasitol. 135, 521-527.

Bishop, M.J., Carnegie, R.B., Stokes, N.A., Peterson, C.H., Burreson, E.M., 2006. Complications of a non-native oyster introduction: facilitation of a local parasite. Mar. Ecol. Prog. Ser. 325, $145-152$.

Bower, S.M., Meyer, G.R., 2002. Morphology and ultrastructure of a protistan parasite in the haemolymph of shrimp (Pandalus spp.) in the northeastern Pacific Ocean. Can. J. Zool. 80, $1055-1068$.

Brehélin, M., Bonami, J.R., Cousserans, F., Vivarès, C.P., 1982. Existence de formes plasmodiales vraies chez Bonamia ostreae parasite de l'huître plate Ostrea edulis. Compte Rendu Hebdomadaire des Séances de l'Académie des Séances, Paris. Série III 295, 45-48. 
Burki, F., Corradi, N., Sierra, R., Pawlowski, J., Meyer, G.R., Abbott, C.L., Keeling, P.J., 2013. Phylogenomics of the intracellular parasite Mikrocytos mackini reveals evidence for a mitosome in rhizaria. Curr. Biol. 23, 1541-1547.

Burreson, E.M., 1994. Further evidence of regular sporulation by Haplosporidium nelsoni in small oysters, Crassostrea virginica. J. Parasitol. 80, 1036-1038.

Burreson, E.M., Ford, S.E., 2004. A review of recent information on the Haplosporidia, with special reference to Haplosporidium nelsoni (MSX disease). Aquat. Living Resour. 17, 499-517.

Burreson, E.M., Reece, K.S., 2006. Spore ornamentation of Haplosporidium nelsoni and Haplosporidium costale (Haplosporidia) and incongruence of molecular phylogeny and spore ornamentation in the Haplosporidia. J. Parasitol. 92, 1295-1301.

Burreson, E.M., Stokes, N.A., Friedman, C.S., 2000. Increased virulence in an introduced pathogen: Haplosporidium nelsoni (MSX) in the eastern oyster Crassostrea virginica. J. Aquat. Anim. Health 12, 1-8.

Burreson, E.M., Stokes, N.A., Carnegie, R.B., Bishop, M.J., 2004. Bonamia sp. (Haplosporidia) found in nonnative oysters Crassostrea ariakensis in Bogue Sound, North Carolina. J. Aquat. Animal Health 16, 1-9. 
Campalans, M., Rojas, P., Gonzalez, M., 2000. Haemocytis parasitosis in the farmed oyster Tiostrea chilensis. Bull. Eur. Assoc. Fish Pathol. 20, 31-33.

Carnegie, R.B., Burreson, E.M., 2011. Declining impact of an introduced pathogen:

Haplosporidium nelsoni in the oyster Crassostrea virginica in Chesapeake Bay. Mar. Ecol. Prog. Ser. 432, 1-15.

Carnegie, R.B., Engelsma, M.Y., 2014. Microcell parasites of molluscs: Introduction to DAO Special 7. Dis. Aquat. Org. 110, 1-4.

Carnegie, R.B., Hill, K.M., Stokes, N.A., Burreson, E.M., 2014. The haplosporidian Bonamia exitiosa is present in Australia, but the identity of the parasite described as Bonamia (formerly Mikrocytos) roughleyi is uncertain. J. Invertebr. Pathol. 115, 33-40.

Carnegie, R.B., Burreson, E.M., Hine, P.M., Stokes, N.A., Audemard, C., Bishop, M.J., Peterson, C.H., 2006. Bonamia perspora n. sp. (Haplosporidia), a parasite of the oyster Ostreola equestris, is the first Bonamia species known to produce spores. J. Eukaryot. Microbiol. 53, 232245.

Carnegie, R.B., Stokes, N.A., Audemard, C., Bishop, M.J., Wilbur, A.E., Alphin, T.D., Posey, M.H., Peterson, C.H., Burreson, E.M., 2008. Strong seasonality of Bonamia sp. infection and induced Crassostrea ariakensis mortality in Bogue and Masonboro Sounds, North Carolina, USA. J. Invertebr. Pathol. 98, 335-343. 
Cranfield, H.J., Dunn, A., Doonan, I.J., Michael, K.P., 2005. Bonamia exitiosa epizootic in Ostrea chilensis from Foveaux Strait, southern New Zealand between 1986 and 1992. ICES J. Mar. Sci. 62, 3-13.

Caullery, M., Mesnil, F., 1899. Sur le genre Aplosporidium (nov) et l'ordre nouveau des Aplosporidies. C. R. Soc. Biol. (Paris) 51, 789-791.

Cochennec, N., Auffret, M., 2002. European project DISENV FAIR984120 'Environmental Factors and Shellfish Diseases’ 15/05/2002 Final Report. Project details available at: http://cordis.europa.eu/

Comps, M., 1970. Observations sur les causes d'une mortalité anormal des huitres plates dans le basin de Marennes. Revue des Travaux de l'Institut des Peches. Maritimes 34, 317-326.

Culloty, S.C., Mulcahy, M.F., 1996. Season-, age-, and sex-related variations in the prevalence of bonamiasis in flat oyster (Ostrea edulis L.) on the south coast of Ireland. Aquaculture 144, 5363.

da Silva, P.M., Fuentes, J., Villalba, A., 2005. Growth, mortality and disease susceptibility of oyster Ostrea edulis families obtained from brood stocks of different geographical origins, through on-growing in the Ría de Arousa (Galicia, NW Spain). Mar. Biol. 147, 965-977. 
Elston, R.A., 1999. Health management, development and histology of seed oysters. Chapter 19. Haplosporidiosis of juvenile oysters. pp. 99-102. World Aquaculture Society, Baton Rouge, Louisiana, USA. 110 pp.

Elston, R.A., Farley, C.A., Kent, M.L., 1986. Occurrence and significance of bonamiasis in European flat oysters Ostrea edulis in North America. Dis. Aquat. Org. 2, 49-54.

Engelsma, M.Y. Culloty, S.C., Lynch, S.A., Arzul, I., Carnegie, R.B., 2014. Bonamia parasites: A rapidly changing perspective on a genus of important mollusc pathogens. Dis. Aquat. Org. $110,5-23$.

Engelsma, M.Y., Kerkhoff, S., Roozenburg, I., Haenen, O.L.M., van Gool, A., Sistermans, W., Wijnhoven, S., Hummel, H., 2010. Epidemiology of Bonamia ostreae infecting European flat oyster Ostrea edulis from Lake Grevelingen, The Netherlands. Mar. Ecol. Prog. Ser. 409, 131142.

Flannery, G., Lynch, S.A., Carlsson, J., Cross, T.F., Culloty, S.C., 2014. Assessment of the impact of a pathogen, Bonamia ostreae, on Ostrea edulis oyster stocks with different histories of exposure to the parasite in Ireland. Aquaculture 432, 243-251.

Ford, S.E., Haskin, H.H., 1982. History and epizootiology of Haplosporidium nelsoni (MSX), an oyster pathogen in Delaware Bay, 1957-1980. J. Invertebr. Pathol. 40, 118-141. 
Ford, S.E., Haskin, H.H., 1988. Comparison of in vitro salinity tolerance of the oyster parasite, Haplosporidium nelsoni (MSX) and hemocytes from the host, Crassostrea virginica. Comp. Biochem. Phys. 90A, 183-187.

Ford, S.E., Allam, B., Xu, Z., 2009. Using bivalves as particle collectors with PCR detection to investigate the environmental distribution of Haplosporidium nelsoni. Dis. Aquat. Org. 83, 159168.

Ford, S.E., Stokes N.A., Burreson, E.M., Scarpa, E., Carnegie, R.B., Kraeuter, J.N., Bushek, D., 2009. Minchinia mercenariae n. sp. (Haplosporidia) in the hard clam Mercenaria mercenaria: Implications of a rare parasite in a commercially important host. J Eukaryot. Microbiol. 56, 542551.

Garcia, C., Arzul, I., Chollet, B., Ferrand, S., François, C., Joly, J.-P., Miossec, L., Robert, M., 2006. Synthesis of 15 years records for Haplosporidium nelsoni in Crassostrea gigas in France. Journal of Shellfish Research 25, 728

Grizel, H., 1985. Etude des recentes epizooties de l'huitre plate Ostrea edulis Linne et de leur impact sur l'ostreiculture bretonne. PhD thesis, Universite des sciences et techniques du Languedoc, Montpellier.

Grizel, H., Héral, M., 1991. Introduction into France of the Japanese oyster (Crassostrea gigas). J. Cons. Int. Explor. Mer. 47, 399-403. 
Grizel, H., Comps, M., Bonami, J.R., Cousserans, F., Duthoit, J.L, Pennec, M., 1974. Epizooty of the common oyster Ostrea edulis. Part 1. Study of the agent of digestive gland disease in Ostrea edulis (Linne). Science Peche 1-30.

Hartikainen, H., Ashford, O.S., Berney, C., Okamura, B., Feist, S.W., Baker-Austin, C., Stentiford, G.D., Bass, D., 2014a. Lineage-specific molecular probing reveals novel diversity and ecological partitioning of haplosporidians. ISME J. 8, 177-186.

Hartikainen, H., Stentiford, G.D., Bateman, K.S., Berney, C., Feist, S.W., Longshaw, M., Okamura, B., Stone, D., Ward, G., Wood, C., Bass, D., 2014b. Mikrocytids are a broadly distributed and divergent radiation of parasites in aquatic invertebrates. Curr. Biol. 24, 807-812.

Haskin, H.H., Andrews, J.D., 1988. Uncertainties and speculations about the life cycle of the eastern oyster pathogen Haplosporidium nelsoni (MSX). Am. Fish. Soc. Spec. Publ. 18, 5-22.

Haskin, H.H., Stauber, L.A., Mackin, J.A., 1966. Minchinia nelsoni n. sp. (Haplosporida, Haplosporidiidae): causative agent of the Delaware Bay oyster epizootic. Science 153, 14141416.

Haven, D.S., Hargis, W.J., Kendal, P.C., 1978. The oyster industry of Virginia: its status, problems and promise. VIMS Special Papers in Marine Science No. 4, Virginia Institute of Marine Science, Gloucester Point, Virginia, USA. 
Hervio, D., Bachère, E., Boulo, V., Cochennec, N., Vuillemin, V., Le Coguic, Y., Cailletaux, G., Mazuri, J., Mialhe, E., 1995. Establishment of an experimental infection protocol for the flat oyster, Ostrea edulis, with the intrahaemocytic protozoan parasite, Bonamia ostreae: application in the selection of parasite-resistant oysters. Aquaculture 132, 183-194.

Hill, K.M., Stokes, N.A., Webb, S.C., Hine, P.M., Kroeck, M.A., Moore, J.D., Morley, M.S., Reece, K.S., Burreson, E.M., Carnegie, R.B., 2014 Phylogenetics of Bonamia parasites based on small subunit and internal transcribed spacer region ribosomal DNA sequence data. Dis. Aquat. Org. 110, 33-54.

Hine, P.M., 1991a. The annual pattern of infection by Bonamia sp. in New Zealand flat oysters, Tiostrea chilensis. Aquaculture 93, 241-251.

Hine, P.M., 1991b. Ultrastructural observations on the annual infection pattern of Bonamia sp. in flat oysters Tiostrea chilensis. Dis. Aquat. Org. 11, 163-171.

Hine, P.M., 2002. Severe apicomplexan infection in the oyster Ostrea chilensis: a possible predisposing factor in bonamiosis. Dis. Aquat. Org. 51, 49-60.

Hine, P.M., Carnegie, R.B., Burreson, E.M., Engelsma, M.Y., 2009. Inter relationships of haplosporidians deduced from ultrastructural studies. Dis. Aquat. Org. 83, 247-256. 
Hine, P.M., Wakefield, S., Diggles, B.K., Webb, V.L., Maas, E.W., 2002. The ultrastructure of a haplsporidian containing Rickettsiae, associated with mortalities among cultured paua Haliotis iris. Dis. Aquat. Org., 49, 207-219.

Hofmann, E., Ford, S., Powell, E., Klinck, and J., 2001. Modeling studies of the effect of climate variability on MSX disease in eastern oyster (Crassostrea virginica) populations. Hydrobiologia 460, 195-212.

Hudson, E.B., Hill, B.J., 1991. Impact and spread of bonamiasis in the UK. Aquaculture 93, 279285.

Ituarte, C., Bagnato, E., Siddall, M.E., Cremonte, F., 2014. A new species of Haplosporidium Caullery \& Mesnil, 1899 in the marine false limpet Siphonaria lessonii (Gastropoda:

Siphonariidae) from Patagonia. Syst. Parasitol. 88, 63-73.

Kamaishi, T. Yoshinaga, T., 2002. Detection of Haplosporidium nelsoni in Pacific oyster Crassostrea gigas in Japan. Fish Pathol. 37, 193-195.

Kroeck, M.A., Semenas, L., Morsan, E.M., 2008. Epidemiological study of Bonamia sp. in the native flat oyster, Ostrea puelchana from San Matías Gulf(NW Patagonia, Argentina).

Aquaculture 276, 5-13 
Lallias, D., Arzul, I., Heurtebise, S., Ferrand, S., Chollet, B., Robert, M., Beaumont, A.R., Boudry, P., Morga, B., Lapègue, S., 2008. Bonamia ostreae-induced mortalities in one-year old European flat oysters Ostrea edulis: experimental infection by cohabitation challenge. Aquat. Living. Res. 21, 423-439.

Lynch, S.A., Armitage, D.V., Coughlan, J., Mulcahy, M.F., Culloty, S.C., 2007. Investigating the possible role of benthic macroinvertebrates and zooplankton in the life cycle of the haplosporidian Bonamia ostreae. Exp. Parasitol. 115, 359-368.

Lynch, S.A., Armitage, D.V., Wylde, S., Mulcahy, M.F., Culloty, S.C., 2005. The susceptibility of young, prespawning oysters, Ostrea edulis, to Bonamia ostreae. J. Shellfish Res. 24, 10191025.

Lynch, S.A., Armitage, D.V., Wylde, S., Mulcahy, M.F., Culloty, S.C., 2006. Inventory of benthic macroinvertebrates and zooplankton in several European Bonamia ostreae-endemic areas and their possible role in the life cycle of this parasite. Mar. Biol. 149, 1477-1487.

Lynch, S.A., Flannery, G., Hugh-Jones, H., Hugh-Jones, D., Culloty, S.C., 2014. Thirty-year history of Irish (Rossmore) Ostrea edulis selectively bred for disease resistance to Bonamia ostreae. Dis. Aquat. Org. 110, 113-121. 
Lynch, S.A., Villalba, A., Abollo, E., Engelsma, M., Stokes, N.A., Culloty, S.C., 2013. The occurrence of haplosporidian parasites, Haplosporidium nelsoni and Haplosporidium sp., in oysters in Ireland'. J. Invertebr. Pathol. 112, 208-212.

Lynch, S.A, Morgan, A., Carlsson, J., Mackenzie, C., Wooton, E.C., Rowley, A.F., Malham, S., Culloty, S.C., 2014. The health status of mussels, Mytilus spp., in Ireland and Wales with the molecular identification of a previously undescribed haplosporidian. J. Invertebr. Pathol. 118, $59-65$.

Marteil, L., 1968. La “maladie des branchies”. Cons. Int. Explor. Mer K: 5.

Mackin, J.G., Owen, H.M., Collier, A., 1950. Preliminary note on the occurrence of a new protistan parasite, Dermocystidium marinum n. sp. in Crassostrea virginica (Gmelin). Science $111,328-329$.

McArdle, J.F., McKiernan, F., Foley, H., Jones, D.H. 1991. The current status of Bonamia disease in Ireland. Aquaculture 93, 273-278.

Mialhe, E., Bachère, E., Chagot, D., Grizel, H., 1988. Isolation and purification of the protozoan Bonamia ostreae (Pichot et al. 1980), a parasite affecting the flat oyster Ostrea edulis L. Aquaculture 71, 293-299. 
Molloy, D.P., Giambérini, L., Stokes, N.A., Burreson, E.M., Ovcharenko, M.A., 2012.

Haplosporidium raabei (Haplosporidia): a parasite of zebra mussels, Dreissena polymorpha (Pallas, 1771). Parasitol. 139, 463-477.

Montes, J., 1990. Development of Bonamia ostreae parasitosis of flat oyster (Ostrea edulis) from Galicia, Northwest Spain. In: Perkins, F.O., Cheng, T.C. (eds.) Pathology in Marine Science. Academic Press, London.

Montes, J., Ferro-Soto, B., Conchas, R.F., Guerra, A., 2003. Determining culture strategies in populations of the European flat oyster, Ostrea edulis, affected by bonamiosis. Aquaculture 220, $175-182$.

Novoa, B., Balseiro, P., Figueras, A., 2004. Molecular detection of a haplosporidian parasite in carpet shell clam Ruditapes decussatus from Spain. Dis. Aquat. Org. 61, 89-93.

Nunan, L.M., Lightner, D.V., Pantoja, C.R., Stokes, N.A., Reece, K.S., 2007. Characterization of a rediscovered haplosporidian parasite from cultured Penaeus vannamai. Dis. Aquat. Org. 74, 67-75.

Paraso, M.C., Ford, S.E., Powell, E.N., Hofmann, E.E., Klinck, J.M., 1999. Modeling the MSX parasite in eastern oyster (Crassostrea virginica) populations. II. Salinity effects. J. Shellfish Res. 18, 501-516. 
Pichot, Y., Comps, M., Tigé, G., Grizel, H. Rabouin, M.-A., 1980. Recherches sur Bonamia ostreae gen. n., sp. n., parasite nouveau de l'huître plate Ostrea edulis. Rev. Trav. Inst. Pêches Marit. 43, 131-140.

Powell, E.N., Klinck, J.M., Ford, S.E., Hofmann, E.E., Jordan, S.J., 1999. Modeling the MSX parasite in eastern oyster (Crassostrea virginica) populations. III. Regional application and the problem of transmission. J. Shellfish Res. 18, 517-537.

Reece, K.S., Stokes, N.A., 2003. Molecular analysis of a haplosporidian parasite from cultured New Zealand abalone Haliotis iris. Dis. Aquat. Org. 53, 61-66.

Reece, K.S., Siddall, M.E., Stokes, N.A., Burreson, E.M., 2004, Molecular phylogeny of the Haplosporidia based on two independent gene sequences. J. Parasitol. 90, 1111-1122.

Robert, R., Borel, M., Pichot, Y., Trut, G., 1991. Growth and mortality of the European oyster Ostrea edulis in the Bay of Arcachon (France). Aquat. Living. Res. 4, 265-274.

Ruesink, J.L, Lenihan, H.S., Trimble, A.C., Heiman, K.W., Micheli, F., Byers, J.E., Kay, M.C., 2005. Introduction of non-native oysters: ecosystem effects and restoration implications. Ann. Rev. Ecol. Evol. Syst. 36, 643-689.

Shilts, M.H., Pascual, M.S., Ó Foighil, D., 2007. Systematic, taxonomic and biogeographic relationships of Argentine flat oysters. Mol. Phylogenet. Evol. 44, 467-473. 
Siddall, M.E., Aquado, M.-T., 2006. Molecular phylogenetic evidence of a haplosporidian parasite infecting the polychaete Syllis nipponica (Imajima, 1966). Parasitol. Res. 99, 309-312.

Stentiford, G.D., Bateman, K.S., Stokes, N.A., Carnegie, R.B., 2013. Haplosporidium littoralis sp. nov.: a crustacean pathogen within the Haplosporidia (Cercozoa, Ascetospora). Dis. Aquat. Org. 105, 243-252.

Sunila, I., Karolus, J., Lang, E.P., Mroczka, M.E., Volk, J., 2000. Transmission of the haplosporidian parasite MSX (Haplosporidium nelsoni) to the eastern oyster Crassostrea virginica in an upweller system. Dis. Aquat. Org. 42, 153-155.

Swofford, D.L., 2002. PAUP*: Phylogenetic analysis using parsimony (*and other methods), version 10. Sinauer Associates, Sunderland, Massachusetts.

Utari, H.B., Senapin, S., Jaengsanong, C., Flegel, T.W., Kruatrachue, M., 2012. A haplosporidian parasite associated with high mortality and slow growth in Penaeus (Litopenaeus) yannamei cultured in Indonesia. J. Invertebr. Pathol. 92, 23-32.

Van Banning, P., 1988. Management strategies to control diseases in the Dutch culture of edible oysters. Am. Fish. Soc. Spec. Publ. 18, 243-245. 
Van Banning, P., 1991. Observations on bonamiasis in the stock of the European flat oyster, Ostrea edulis, in the Netherlands, with special reference to the recent developments in Lake Grevelingen. Aquaculture 93, 205-211.

Vea, I.M., Siddall, M.E., 2011. Scanning electron microscopy and molecular characterization of a new Haplosporidium species (Haplosporidia), a parasite of the marine gastropod Siphonaria pectinata (Mollusca: Gastropoda: Siphonariidae) in the Gulf of Mexico. J. Parasitol. 97, 10621066.

Winters, A.D., Faisal, M., 2014. Molecular and ultrastructural characterization of Haplosporidium diporeiae n. sp., a parasite of Diporeia sp. (Amphipoda, Gammaridea) in the Laurentian Great Lakes (USA). Parasites and Vectors 7, 343. 
Table 1.

Haplosporidian species described since the publication of Burreson and Ford (2004).

\begin{tabular}{|c|c|c|c|}
\hline Species & Host & Location & References \\
\hline Bonamia perspora & Oyster Ostrea stentina & North Carolina, USA & Carnegie et al. 2006 \\
\hline Minchinia occulta & $\begin{array}{l}\text { Oyster Saccostrea } \\
\text { cuccullata }\end{array}$ & Western Australia & Bearham et al. 2008a \\
\hline Minchinia mercenariae & $\begin{array}{l}\text { Clam Mercenaria } \\
\text { mercenaria }\end{array}$ & $\begin{array}{l}\text { Virginia and New Jersey, } \\
\text { USA }\end{array}$ & Ford et al. 2009 \\
\hline Haplosporidium montforti & $\begin{array}{l}\text { Abalone Haliotis } \\
\text { tuberculata }\end{array}$ & Galicia, Spain & Azevedo et al. 2006 \\
\hline Haplosporidium hinei ${ }^{1}$ & $\begin{array}{l}\text { Pearl oyster Pinctada } \\
\text { maxima }\end{array}$ & Western Australia & Bearham et al. 2008b \\
\hline Haplosporidium tuxtlensis & $\begin{array}{l}\text { Gastropod Siphonaria } \\
\text { pectinata }\end{array}$ & Veracruz, Mexico & Vea and Siddall 2011 \\
\hline Haplosporidium raabei & $\begin{array}{l}\text { Mussel Dreissena } \\
\text { polymorpha }\end{array}$ & $\begin{array}{l}\text { France, Germany, The } \\
\text { Netherlands }\end{array}$ & Molloy et al. 2012 \\
\hline Haplosporidium littoralis & Crab Carcinus maenus & England & Stentiford et al. 2013 \\
\hline Haplosporidium patagon & $\begin{array}{l}\text { Gastropod Siphonaria } \\
\text { lessonii }\end{array}$ & Patagonia, Argentina & Ituarte et al. 2014 \\
\hline Haplosporidium diporeiae & Diporeia spp. amphipods & $\begin{array}{l}\text { Lakes Superior and } \\
\text { Michigan, USA }\end{array}$ & Winters and Faisal 2014 \\
\hline
\end{tabular}

${ }^{1}$ Generic assignment made based on spore structure, with molecular data absent 
Table 2.

Recent observations of undescribed haplosporidians.

\begin{tabular}{|c|c|c|c|}
\hline Identification & Host & Location & References \\
\hline Bonamia sp. & Oyster Ostrea chilensis & Chile & $\begin{array}{l}\text { Campalans et al. 2000; } \\
\text { Hill et al. } 2014\end{array}$ \\
\hline Bonamia sp. & Oyster Ostrea edulis & California, USA & Hill et al. 2014 \\
\hline Bonamia sp. & $\begin{array}{l}\text { Oyster Dendostrea } \\
\text { sandvicensis }\end{array}$ & Hawaii, USA & Hill et al. 2014 \\
\hline Minchinia sp. & Clam Cyrenoida floridana & Mississippi, USA & Reece et al. 2004 \\
\hline Minchinia sp. & Mussel Mytilus edulis ${ }^{1}$ & Wales, United Kingdom & Lynch et al. 2014 \\
\hline Urosporidium sp. & Trematode Stictodora lari & $\begin{array}{l}\text { New South Wales, } \\
\text { Australia }\end{array}$ & Reece et al. 2004 \\
\hline Haplosporidium sp. & Oyster Ostrea edulis & The Netherlands, Ireland & $\begin{array}{l}\text { Engelsma and Haenan, } \\
\text { unpubl.; Lynch et al. } 2013\end{array}$ \\
\hline Not designated & $\begin{array}{l}\text { Shrimp Pandalus } \\
\text { platyceros }\end{array}$ & British Columbia, Canada & $\begin{array}{l}\text { Bower and Meyer 2002; } \\
\text { Reece et al. } 2004\end{array}$ \\
\hline Not designated & $\begin{array}{l}\text { Clam Ruditapes } \\
\text { decussatus }\end{array}$ & Galicia, Spain & Novoa et al. 2004 \\
\hline Not designated & $\begin{array}{l}\text { Polychaete Syllis } \\
\text { nipponica }^{1}\end{array}$ & Japan & Siddall and Aguado 2006 \\
\hline Not designated & $\begin{array}{l}\text { Shrimp Litopenaeus } \\
\text { vannamei }\end{array}$ & Belize & Nunan et al. 2007 \\
\hline Not designated & $\begin{array}{l}\text { Shrimp Litopenaeus } \\
\text { vannamei }\end{array}$ & Indonesia & Utari et al. 2012 \\
\hline
\end{tabular}

${ }^{1}$ Based on genetic detection without microscopic visualization. 


\section{FIGURE LEGENDS}

Fig. 1. Parsimony bootstrap consensus tree of haplosporidian sequences presently available in the GenBank database. Numbers at nodes represent percentages of 1000 bootstrap replicates, with only percentages above $50 \%$ shown.

Fig. 2. Infection dynamics of Bonamia ostreae in Ostrea edulis, with perspective on dispersal and environmental controls.

Fig. 3. Infection dynamics of Haplosporidium nelsoni in Crassostrea virginica, strongly influenced by temperature and salinity but with the parasite's environmental ecology, including the identity of an intermediate host or hosts, a great unknown.

Fig. 4. Cell forms displayed by haplosporidians infecting molluscs. A. Bonamia exitiosa in Crassostrea ariakensis, with parasite cells abundant infecting hemocytes (arrows) and in heavier infections free in hemal spaces (arrowheads). Phloxine-tartrazine staining courtesy of Chris Dungan, Maryland (USA) Department of Natural Resources. B. Bonamia perspora infecting Ostrea stentina from North Carolina, USA, visualized using in situ hybridization with DNA probes. Black staining indicates uninucleate parasite cells particularly abundant along the epithelium of a hemolymph sinus (arrows). C. Haplosporidium nelsoni in Crassostrea virginica, with plasmodia present in connective tissues (arrows) and a mass of spores in digestive tubule epithelium (arrowhead). Scale bars $=20$ microns. 
Fig. 5. In situ hybridization to Bonamia ostreae cells in Ostrea edulis gill epithelia. Scale bar = 10 microns. 


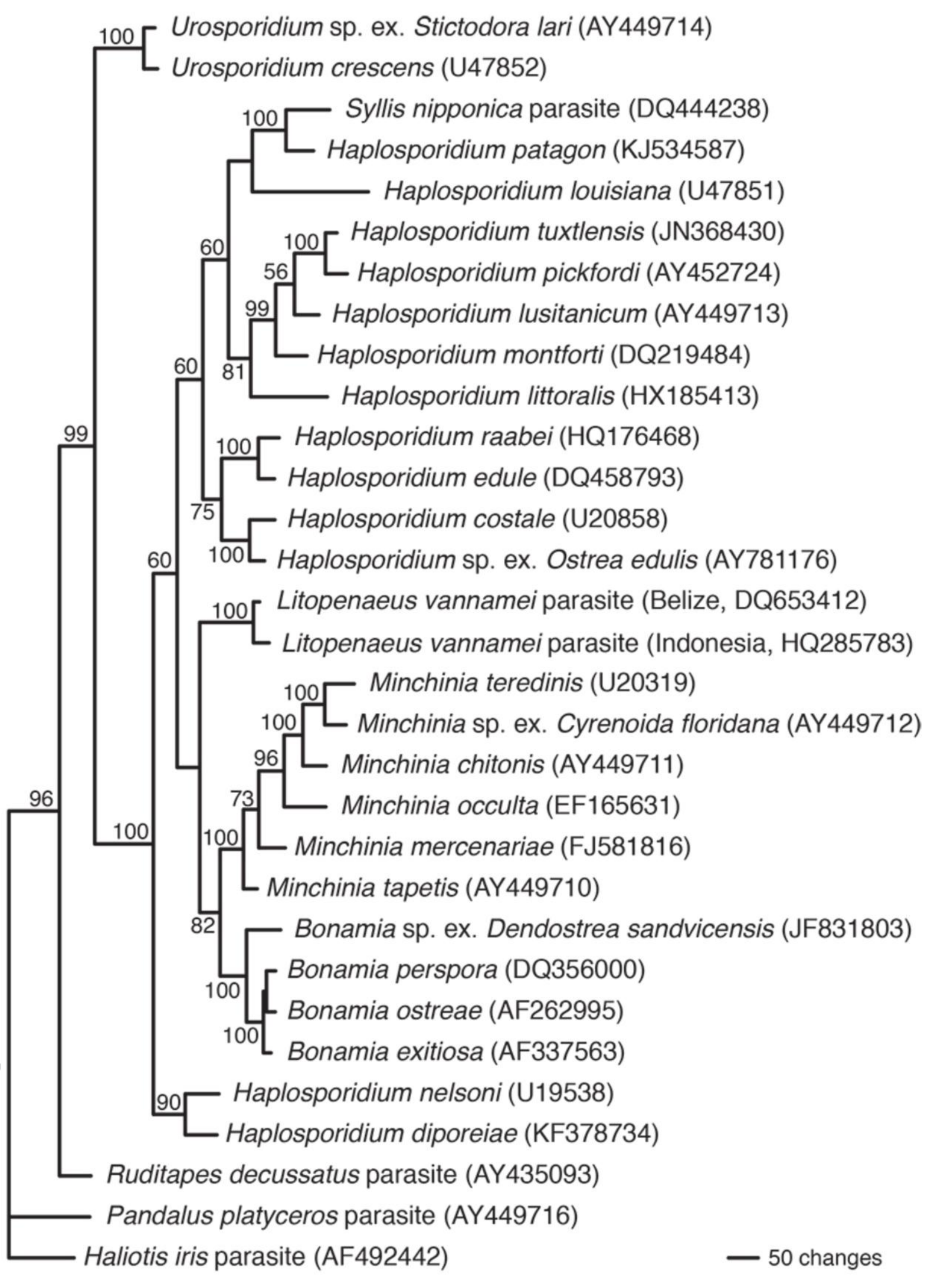

Fig. 1 


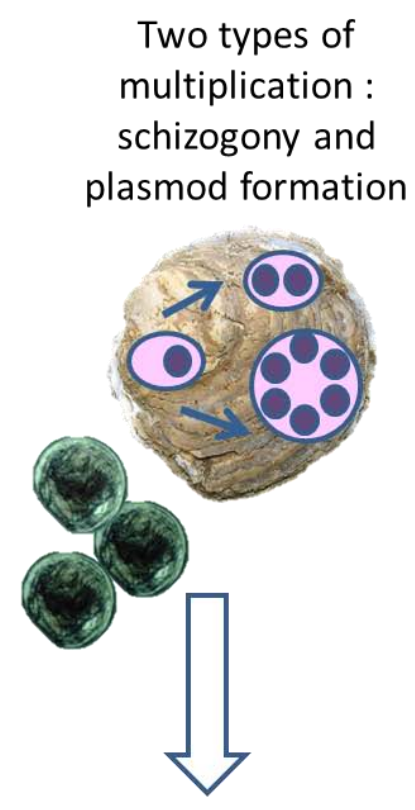

Planktonic stage of larvae: another route of parasite spread

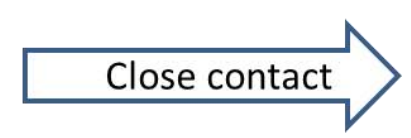

Parasite in the water column

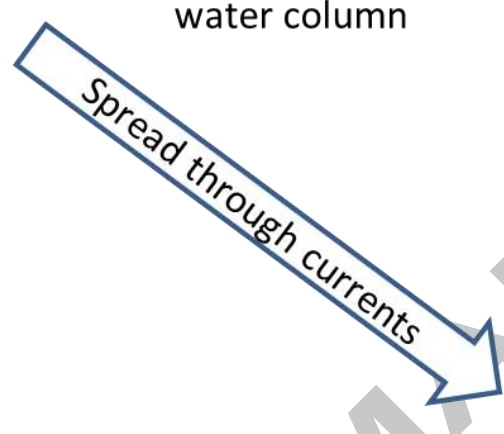

Survival of the parasite in sea water influenced by temperature and salinity

Fig. 2 
Sporulation depends on food availability

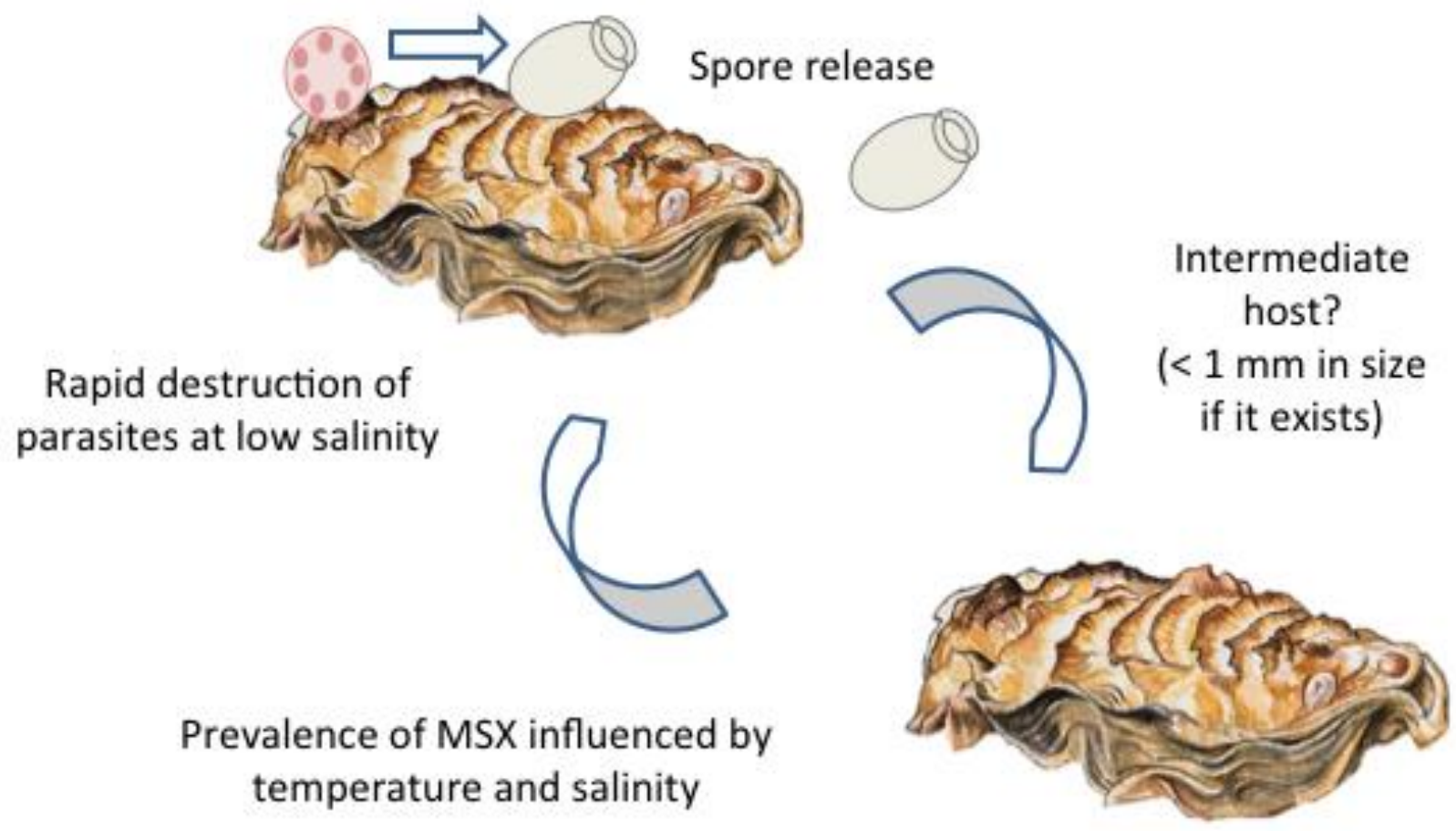

Fig. 3 


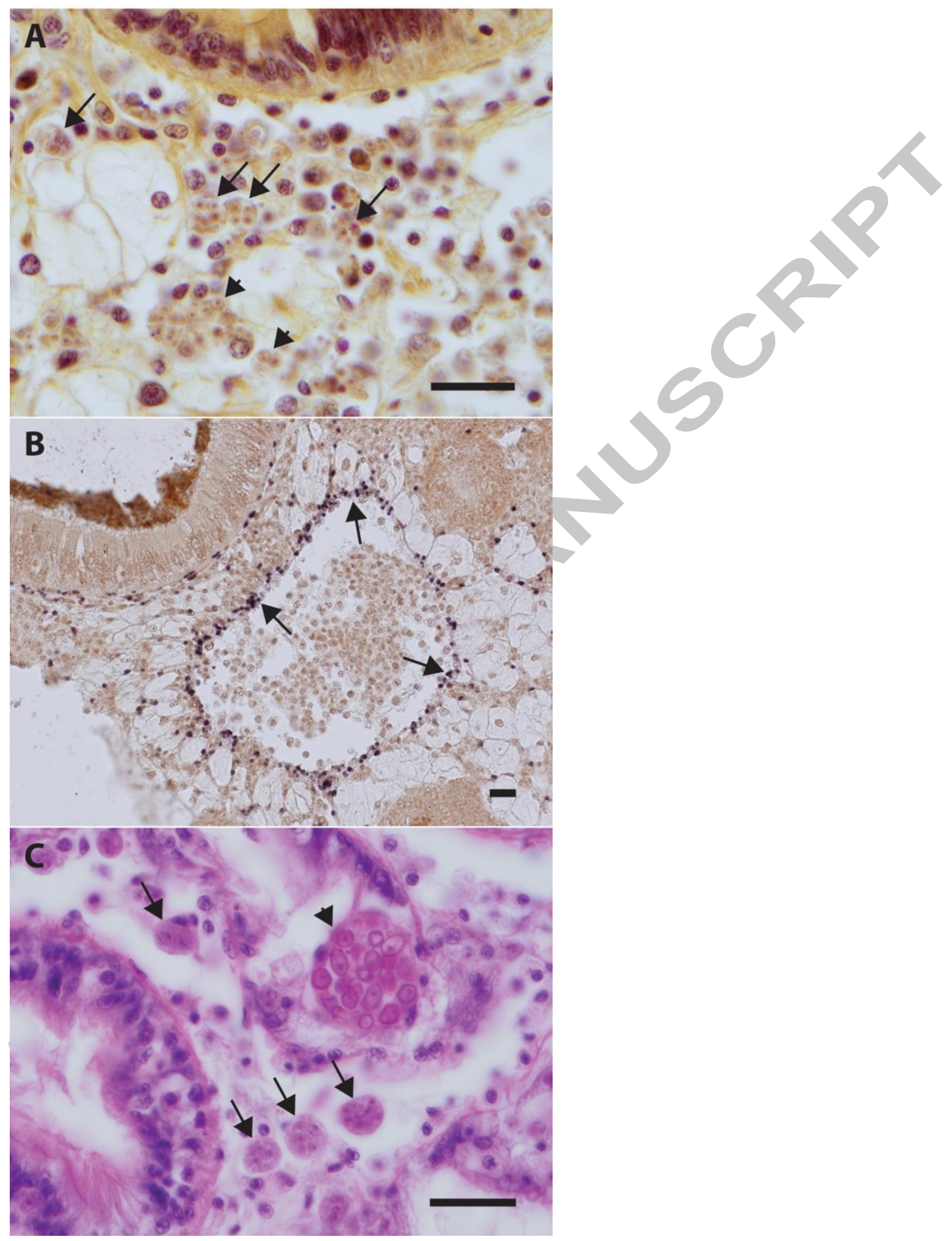

Figure 4 


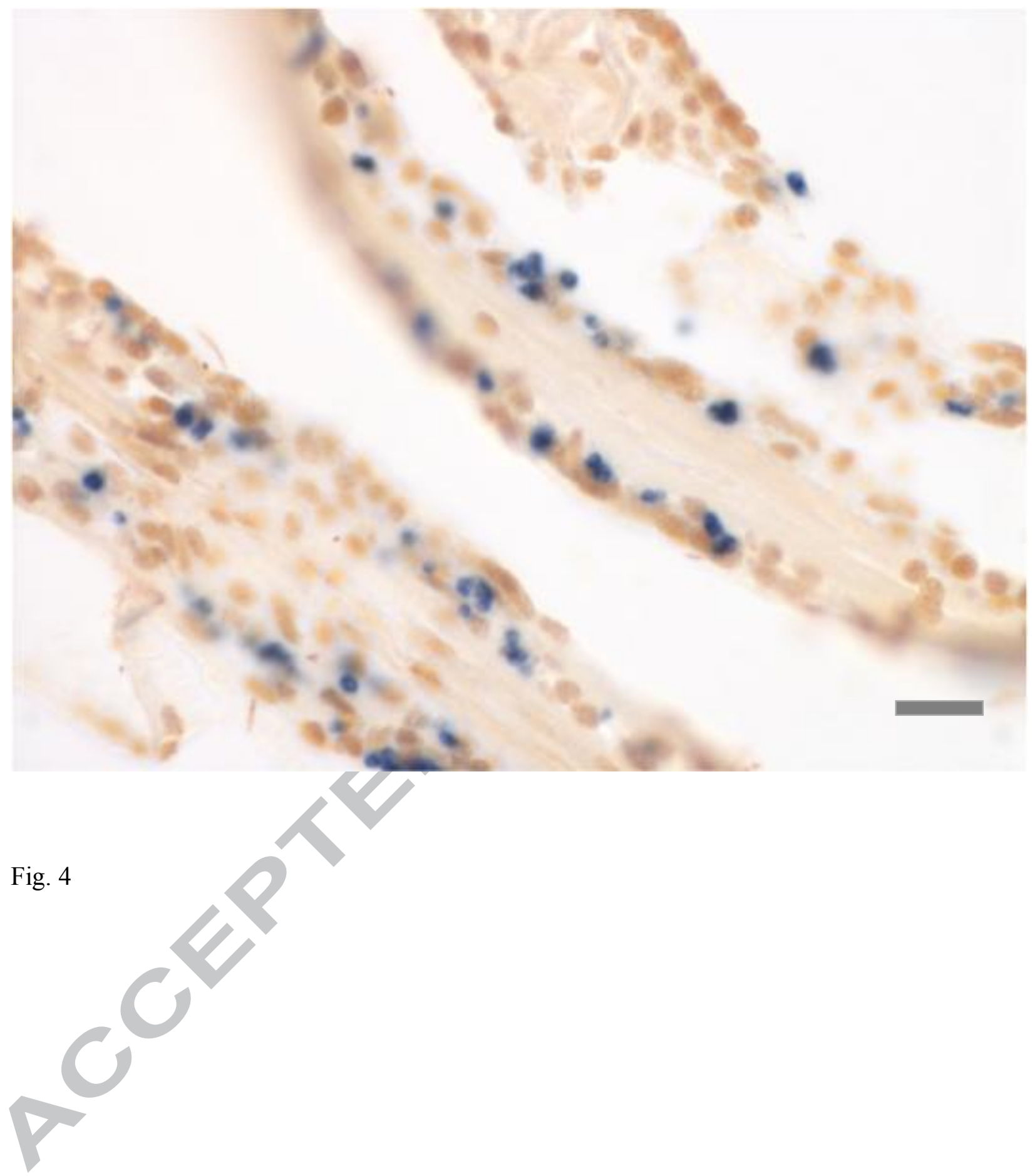

